\title{
The Effect of Paclitaxel on the Viability of U14 Cells
}

\author{
Gao Xuesong ${ }^{1}$, Lin Shaoqiang ${ }^{2}$, Wang Xiaoyu ${ }^{1,}$, \\ ${ }^{1}$ Department of Obstetrics and Gynecology, The First Affiliated Hospital of Jinan University, Guangzhou, China \\ ${ }^{2}$ The Hospital Management Department of Guangdong Pharmaceutical University, Guangzhou, China
}

Email address:

twxy@jnu.edu.cn (Wang Xiaoyu)

${ }^{*}$ Corresponding author

\section{To cite this article:}

Gao Xuesong, Lin Shaoqiang, Wang Xiaoyu. The Effect of Paclitaxel on the Viability of U14 Cells. Journal of Gynecology and Obstetrics. Vol. 8, No. 3, 2020, pp. 51-54. doi: 10.11648/j.jgo.20200803.11

Received: April 18, 2020; Accepted: April 29, 2020; Published: May 11, 2020

\begin{abstract}
The research is aimed to study the effect of paclitaxel on the viability of U14 cell line of cervical cancer, and to provide new ideas for further exploring the mechanism of paclitaxel chemotherapy to cervical cancer. Then, different concentrations of paclitaxel were used to treat U14 cells of cervical cancer in logarithmic phase growth. After culturing these cells for $24 \mathrm{~h}, 48 \mathrm{~h}$ or $72 \mathrm{~h}$, MTT method and automatic enzyme-linked immunosorbent assay system were used to evaluate the survival rate of cultured cells with different concentrations of paclitaxel. These results showed that paclitaxel has a significant inhibitory effect on the proliferation of U14 cells in a concentration- and time-dependent manner, compared with the control group. Paclitaxel concentration of the IC50 of U14 cells was $168.8 \mu \mathrm{g} / \mathrm{ml}$ at $24 \mathrm{~h}, 22.15 \mu \mathrm{g} / \mathrm{ml}$ at $48 \mathrm{~h}$ and $8.04 \mu \mathrm{g} / \mathrm{ml}$ at $72 \mathrm{~h}$. As the time increased, the IC50 value of U14 cells gradually decreased. The results of linear regression analysis are as follows: $24 \mathrm{~h}$, $y=-0.005 x+1.344, R^{2}=0.779 ; 48 h, y=-0.013 x+0.788, R^{2}=0.923 ; 72 h, y=-0.056 x+0.950, R^{2}=0.908$. The dose-effect curve of paclitaxel on U14 cells for $48 \mathrm{~h}$ and the trend of linear regression fitting are better, and the growth inhibition of cells shows a clear relationship between time and dose. In conclusion, paclitaxel has an obvious inhibitory effect on the activity of cervical cancer U14 cells in mice, which provides new ideas for further exploring the mechanism of cervical cancer paclitaxel chemotherapy.
\end{abstract}

Keywords: Paclitaxel, Cervical Cancer, Cell Viability, U14 Cell

\section{Introduction}

Cervical cancer is the second highest incidence of malignant tumors in women and the third leading cause of death of women with malignant tumors [1]. According to the statistics of China in recent years, the incidence of cervical cancer among women has been increasing year by year [2]. At present, the main treatment methods for cervical cancer are surgery, radiation therapy and chemotherapy, but the survival rate of patients has not been significantly improved [3, 4]. It seriously threatens women's health. Paclitaxel was first isolated and extracted from the bark of pacific yew in the 1960s and was elucidated in 1971 [5]. It is now a semi-chemical synthesis with extensive and obvious biological activity. Its main anti-tumor mechanism is to promote the polymerization of tubulin dimer and stabilize the microtubules, thereby inhibiting the normal dynamic reorganization of the microtubule network, which is important for the function of interphase and mitotic cells [6]. And it leads to the abnormal arrangement of microtubule bundles, affecting tumor cell division [7].

In recent years, paclitaxel has become a commonly used treatment for advanced cervical cancer chemotherapy $[8,9]$. Studies have shown that changes in the microtubule dynamics are significantly associated with cell carcinogenesis, tumor progression, metastasis, and prognosis. However, the mechanism of cervical cancer occurrence and development is very complicated [10]. This experiment aims to provide new ideas for further exploring the mechanism of paclitaxel chemotherapy for cervical cancer by observing the effect of paclitaxel on the activity of U14 cells of cervical cancer.

\section{Materials and Methods}

\subsection{Paclitaxel}

Paclitaxel was purchased from Bristol-Myers Squibb Corporation. Paclitaxel: (MWt: 853.9) Measured value: 853.9; $30 \mathrm{mg} / 5 \mathrm{ml}$, sterile packaging, $1 \mathrm{ml}(6 \mathrm{mg} / \mathrm{ml})$ per bottle, 
refrigerated at $4^{\circ} \mathrm{C}$. It is used for experiments.

\subsection{Cell Lines and Culture}

Mouse cervical cancer U14 is squamous cell carcinoma. It is ectopic cervical cancer induced by treating the cervix with 20-methylcholanthracene. The cell line was purchased from the Cell Bank of the Institute of Basic Medicine, Peking Union Medical College (Beijing, China). Resource number was 3111C0001CCC000238. In Dulbecco's modified Eagle's medium (DMEM; high glucose, Gibco, United States) supplemented with $10 \%$ fetal bovine serum (FBS, Gibco, United States), $100 \mathrm{U} / \mathrm{ml}$ penicillin and $100 \mathrm{U} / \mathrm{ml}$ streptomycin sulfate, in humidified The cells were cultured in an incubator (Thermo Forma USA) $5 \% \mathrm{CO}_{2}$ at $37^{\circ} \mathrm{C}$. Cells were digested with a $0.25 \%$ trypsin (Gibco) solution prepared in D-Hank solution. Subculture every 48 hours. All subsequent experiments are performed when the cells are in the logarithmic growth phase.

\subsection{MTT Colorimetric Assay}

The MTT colorimetric assay [11] was used to evaluate the effect of paclitaxel on the viability of U14 cells. In short, log phase U14 cells $(4 \times 104 / \mathrm{ml})$ were seeded in 96-well culture plates and cultured at $37^{\circ} \mathrm{C}, 5 \% \mathrm{CO}_{2}$ and atmospheric pressure for $24 \mathrm{~h}$. After the cells adhered, the medium was removed. The cells were incubated in $200 \mu \mathrm{l}$ medium containing 7 different concentrations of paclitaxel, where the final concentrations of paclitaxel were $60 \mu \mathrm{g} / \mathrm{ml}, 15 \mu \mathrm{g} / \mathrm{ml}, 3.75$ $\mu \mathrm{g} / \mathrm{ml}, 0.938 \mu \mathrm{g} / \mathrm{ml}, 0.234 \mu \mathrm{g} / \mathrm{ml}, 0.059 \mu \mathrm{g} / \mathrm{ml}$ and $0.015 \mu \mathrm{g} / \mathrm{ml}$. The control group was cultured with the same amount of medium without adding drugs. Each concentration of paclitaxel group and control group consisted of 4 parallel wells. These cells were cultured for $24 \mathrm{~h}, 48 \mathrm{~h}$ and $72 \mathrm{~h}$ respectively. Add $20 \mu \mathrm{l}$ of 3- (4,5-dimethylthiazol-2-yl) -2,5-diphenyltetrazole bromide (MTT, Sigma-Aldrich, USA) $(5 \mathrm{mg} / \mathrm{ml})$ to each well, and further incubate at $37^{\circ} \mathrm{C}$ for 4 hours. In order to stop the reaction, the medium was removed, and $100 \mu \mathrm{l}$ of DMSO (Sigma-Aldrich, USA) was added (added) at $37^{\circ} \mathrm{C}$ on a micro-shaker for $15 \mathrm{~min}$. The absorbance was measured at $570 \mathrm{~nm}$ using an automated enzyme-linked immunosorbent assay system (BIO-RAD, USA). The cell survival rate of paclitaxel cultured at different concentrations was calculated. Cell survival rate $(\%)=(\mathrm{A} 570$ value of the experimental group with added paclitaxel / A570 value of the untreated group) $\times 100 \%$. The average value obtained from the experiment were used to construct the time-concentration curve. The dose-response curve of paclitaxel was obtained by plotting the paclitaxel concentration-cell viability curve, and linear regression was performed. The logit method was used to calculate the $50 \%$ inhibition rate of paclitaxel concentration (IC50). The optimal concentration and time of paclitaxel were screened for follow-up study. This experiment was repeated 3 times.

\section{Results}

\section{Effect of paclitaxel on U14 cell viability}

With the increase of paclitaxel concentration gradient and the extension of time, the survival rate of U14 cells showed a downward trend. Compared with the control group, paclitaxel has a significant inhibitory effect on the proliferation of U14 cells in a concentration- and time-dependent manner (Figure 1). IC50 of U14 cells at different time were shown as follows: $24 \mathrm{~h}$, IC $50=168.8 \mu \mathrm{g} / \mathrm{ml} ; 48 \mathrm{~h}$, IC50 $=22.15 \mu \mathrm{g} / \mathrm{ml} ; 72 \mathrm{~h}$, IC $50=8.04 \mu \mathrm{g} / \mathrm{ml}$. As the time of paclitaxel treatment increased, the IC50 value gradually decreased.
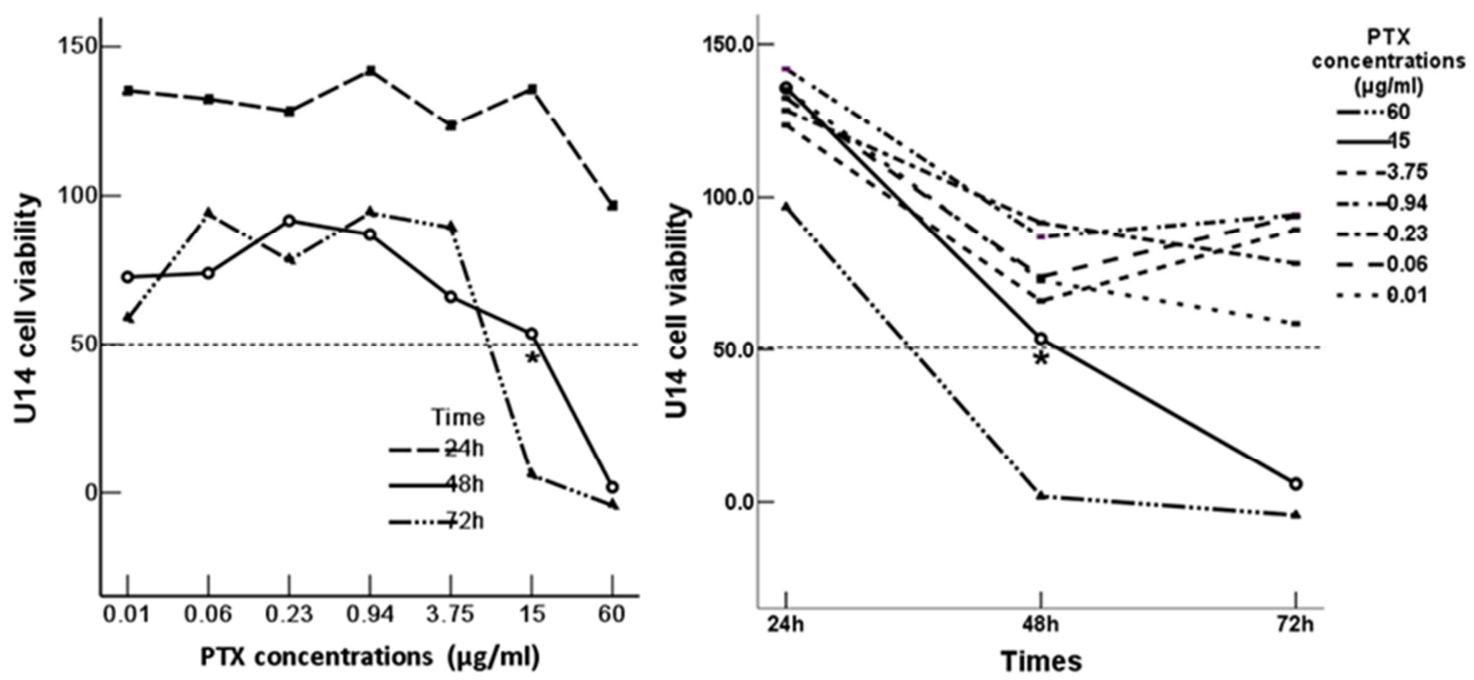

Figure 1. Growth inhibition of paclitaxel in U14 cells viability at the indicated concentration and time. * means IC50.

The results of linear regression analysis are as follows: $24 \mathrm{~h}$, $\mathrm{y}=-0.005 \mathrm{x}+1.344, \mathrm{R}^{2}=0.779 ; 48 \mathrm{~h}, \mathrm{y}=-0.013 \mathrm{x}+0.788$, $\mathrm{R}^{2}=0.923 ; 72 \mathrm{~h}, \mathrm{y}=-0.056 \mathrm{x}+0.950, \mathrm{R}^{2}=0.908$. The effect of paclitaxel on U14 cells for $48 \mathrm{~h}$ was better with the trend of linear regression fitting, and the growth inhibition of the cells shows a significant time-effect and dose-effect relationship (Figures 1, 2). Therefore, the IC50 value of $48 \mathrm{~h}$ was 22.15 $\mu \mathrm{g} / \mathrm{ml}$ which was suit for subsequent experiments that exploring the effect of paclitaxel on U14 cells. 

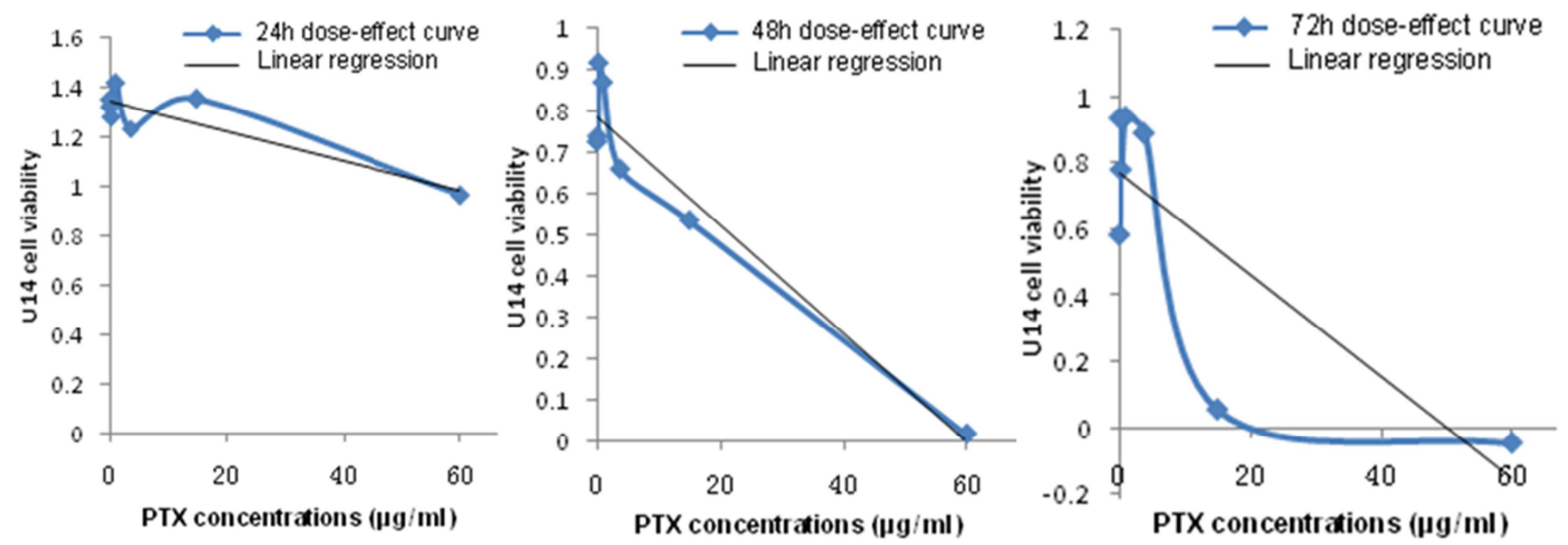

Figure 2. The dose-effect curve and linear regression of mouse cervical cancer cell line U14 treated with various concentrations $(0.015 \mu \mathrm{g} / \mathrm{ml} \sim 60 \mu \mathrm{g} / \mathrm{ml})$ of paclitaxel for $24 \mathrm{~h}, 48 \mathrm{~h}$ and $72 \mathrm{~h}$.

\section{Discussion}

Cervical cancer is a common malignant tumor in the clinic, and there may be obvious enhancement of cancer cell invasion and metastasis ability, epithelial-mesenchymal transition, tumor heterogeneity and other changes in the advanced stage, resulting in the reduction of sensitivity of cancer cells to anti-cancer drugs. Paclitaxel can significantly inhibit the biological activity of cancer cells in the treatment of cervical cancer [12], but it may also cause chemotherapy failure due to the occurrence of multi-drug resistance [13]. Therefore, how to improve the effect of anticancer drugs on cervical cancer, reduce the resistance of cancer cells to chemotherapy drugs, and increase the sensitivity of cancer cells to drugs is an important issue.

Paclitaxel is an efficient, strong, and broad-spectrum cell cycle-specific anti-tumor drug that can synergize with multiple anti-cancer drugs and sensitize radiotherapy [14]. Bava et al. pointed out that MTT assay is a very convenient method to evaluate paclitaxel drug sensitivity. Paclitaxel is highly cytotoxic to human-derived cervical cancer of HeLa, $\mathrm{SiHa}$, CaSki and ME-180 cell lines [15]. The cytotoxicity induced by $5 \mathrm{nmol} / \mathrm{L}$ and $10 \mathrm{nmol} / \mathrm{L}$ Paclitaxel was $17 \%$ and $50 \%$, respectively [15]. In this study, paclitaxel had a poor growth inhibition effect on U14 cells during the 24-hour period. However, paclitaxel had certain cytotoxicity in the 48-hour period and 72-hour period. As the prolonged toxic effect increases, and the proliferation and survival of U14 cells are gradually inhibited.

\section{Conclusion}

In conclusion, this study initially explored paclitaxel's anti-cervical cancer cell of U14's activity, and the results showed that paclitaxel had a significant inhibitory effect on U14 cell activity, which provides new evidence for paclitaxel's treatment of cervical cancer. In addition, paclitaxel's inhibitory effect on U14 cells was a concentration- and time-dependent manner, which also provide a reference for clinical use.

\section{References}

[1] Small W, Jr., Bacon MA, Bajaj A, Chuang LT, Fisher BJ, Harkenrider MM, Jhingran A, Kitchener HC, Mileshkin LR, Viswanathan AN, Gaffney DK. Cervical cancer: A global health crisis. Cancer 2017, 123 (13): 2404-2412.

[2] Song B, Ding C, Chen W, Sun H, Zhang M, Chen W. Incidence and mortality of cervical cancer in China, 2013. Chinese journal of cancer research 2017, 29 (6): 471-476.

[3] Yang K, Park W, Huh SJ, Bae DS, Kim BG, Lee JW. Clinical outcomes in patients treated with radiotherapy after surgery for cervical cancer. Radiation oncology journal 2017, 35 (1): 39-47.

[4] Lee SY, Lee NR, Cho DH, Kim JS. Treatment outcome analysis of chemotherapy combined with modulated electro-hyperthermia compared with chemotherapy alone for recurrent cervical cancer, following irradiation. Oncology letters 2017, 14 (1): 73-78.

[5] Wall ME. Camptothecin and paclitaxel: discovery to clinic. Medicinal research reviews 1998, 18 (5): 299-314.

[6] Naaz F, Haider MR, Shafi S, Yar MS. Anti-tubulin agents of natural origin: Targeting paclitaxel, vinca, and colchicine binding domains. European journal of medicinal chemistry 2019, 171: 310-331.

[7] Chavez JD, Keller A, Zhou B, Tian R, Bruce JE. Cellular Interactome Dynamics during Paclitaxel Treatment. Cell reports 2019, 29 (8): 2371-2383 e2375.

[8] Wang H, Zhu Y, Hao C, Fan J, Liu Y, Wang Y. Establishment of a drug-resistant human cervical cancer cell line and research on its drug-resistance. Journal of cancer research and therapeutics 2019, 15 (6): 1221-1225.

[9] Lee BE, Choi BY, Hong DK, Kim JH, Lee SH, Kho AR, Kim H, Choi HC, Suh SW. The cancer chemotherapeutic agent paclitaxel (Paclitaxel) reduces hippocampal neurogenesis via down-regulation of vesicular zinc. Scientific reports 2017, 7 (1): 11667.

[10] Aborehab NM, Osama N. Effect of Gallic acid in potentiating chemotherapeutic effect of Paclitaxel in HeLa cervical cancer cells. Cancer cell international 2019, 19: 154. 
[11] Zheng FY, Wang SG, Hou WX, Xiao YC, Liu PC, Shi XY, Shen MW. Comparative study of resazurin reduction and MTT assays for cytocompatibility evaluation of nanofibrous materials. Anal Methods-Uk 2019, 11 (4): 483-489.

[12] Lee KH, Yim EK, Kim CJ, Namkoong SE, Um SJ, Park JS. Proteomic analysis of anti-cancer effects by paclitaxel treatment in cervical cancer cells. Gynecologic oncology 2005, 98 (1): 45-53.

[13] Mao BD, Xu P, Xu P, Zhong Y, Ding WW, Meng QZ. LINC00511 knockdown prevents cervical cancer cell proliferation and reduces resistance to paclitaxel. Journal of biosciences 2019, 44 (2).
[14] Zhu L, Chen L. Progress in research on paclitaxel and tumor immunotherapy. Cellular \& molecular biology letters 2019, 24 : 40.

[15] Bava SV, Puliyappadamba VT, Deepti A, Nair A, Karunagaran D, Anto RJ. Sensitization of paclitaxel-induced apoptosis by curcumin involves down-regulation of nuclear factor- $\mathrm{B}$ and the serine/threonine kinase Akt and is independent of tubulin polymerization (vol 280, pg 6301, 2005). Journal of biological chemistry 2018, 293 (31): 12283-12283. 